\title{
Strawberry Production Problems and Management
}

ISSN: 2637-7659

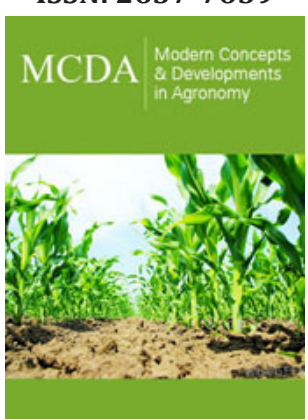

*Corresponding author: Özarslandan A, Applied Technology and Management School of Silifke, Mersin University, 33940, Silifke Mersin, Turkey

Submission: 制 January 23, 2020

Published: 侮February 06, 2020

Volume 5 - Issue 5

How to cite this article:

Özarslandan A. Strawberry Production Problems and Management. Mod Concep Dev Agrono.5(5). MCDA.000624.2020. DOI: 10.31031/MCDA.2020.05.000624

Copyright@ Özarslandan A, This article is distributed under the terms of the Creative Commons Attribution 4.0 International License, which permits unrestricted use and redistribution provided that the original author and source are credited.

\section{Özarslandan A*}

Applied Technology and Management School of Silifke, Mersin University, Turkey

\section{Abstract}

Soil pathogens cause economic yield losses in strawberry production areas. At the same time, Strawberry leaf nematode causes loss of yield and quality. Fumigant applications should be done by solarization against soil pathogens. Seedlings not smeared with strawberry leaf nematode should be used. Leaf wetness and moisture should be reduced to prevent the proliferation of strawberry leaf nematodes. According to the climate in which the producers are located, they have to struggle integratedly to grow the plant healthy. . Integrated struggle should be done to increase the yield and quality in the strawberry fields.

\section{Introduction}

Strawberry production is 440968 tons in 161021 decares in Turkey [1]. For this reason, it is necessary to include combined applications in the fight against nematode and soil-borne pathogens to increase the effect and to protect the soil and the environment [2,3]. There are many plant parasitic nematode species in strawberry fields. Nematodes damage the roots of plants and prevent the plant's water and nutrient uptake. They reduce the root volume of plants. Accordingly, there are efficiency and quality losses. In addition, nematodes directly open the entrance to fungal factors in addition to their direct damage. Strawberry plants showing signs of root rot, It has been reported that M. phaseolina 48\%, Fusarium spp. 40s\%, R. solani $8 \%$, A. alternata $2 \%$ and A. niger 1\% [4]. Together, nematodes and root diseases do more damage to the strawberry plant. Strawberry yield typically decreases over time due to these root pathogens (Figure 1). Plant growth is poor when the root of sick seedlings are planted.

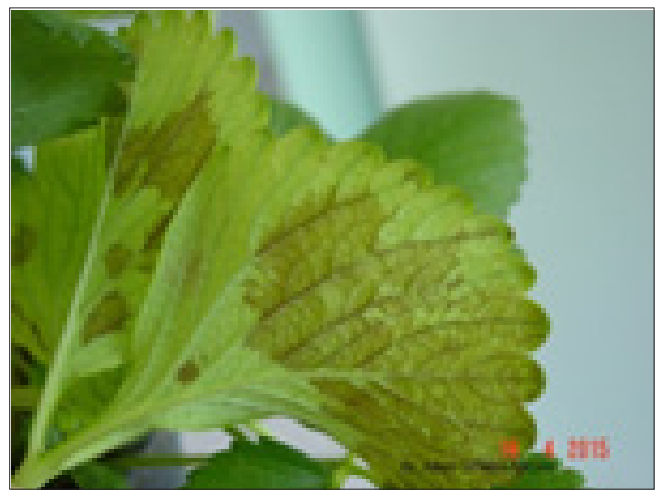

Figure 1: strawberry leaf nematode symptom

Re-seedling plantings are one of the most expensive aspects of strawberry production. Strawberry growers should take steps to prevent nematode problems to increase yield and quality. Strawberry seedlings are mostly produced in cool regions in our country [5]. As soil fumigation is not performed in seedling production areas, the roots become black as a result of plant parasitic nematodes and fungal infections. Starting production with patient seedlings increases input costs such as medicine and fertilizers (Figure 2). Producers do not solarization before planting seedlings. They process fumigation under black mulch. Since black plastic does not pass heat down, the effects of fumigants are low due to low temperature. The producers think that they have done soil disinfection exactly [6]. However, plant disinfection decreases due to plant parasitic nematodes and fungal factors since soil disinfection is not good. In Silifke Mersin, when fumigation under black plastic and fumigation under solarization was 
compared, it was determined that the solarization plastic had twice the efficiency of the other. When strawberry seedlings are planted in early August, seedling deaths vary from year to year (Figure 3). Producers hold seedling producers responsible for seedling deaths. However, when kaolin was thrown on black plastic at the time of planting the seedlings, it was determined that there were no seedling deaths. When the temperature is over $40^{\circ} \mathrm{C}$ in August, strawberry seedling deaths increase with the wind. In order to prevent strawberry seedling deaths, measures such as kaolin and lime should be taken on black plastic.

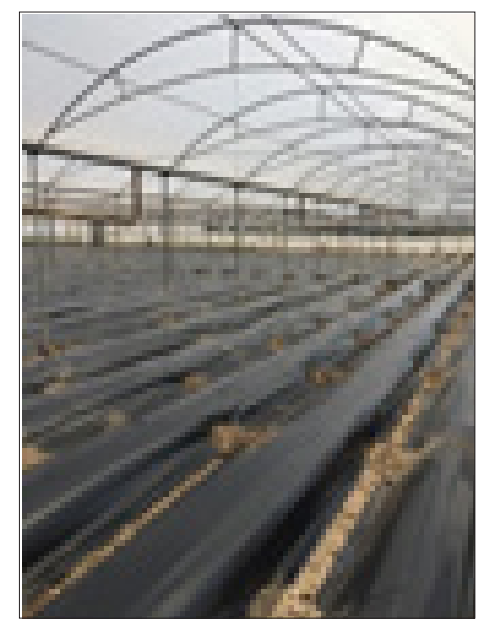

Figure 2: Black plastic and fumigation.

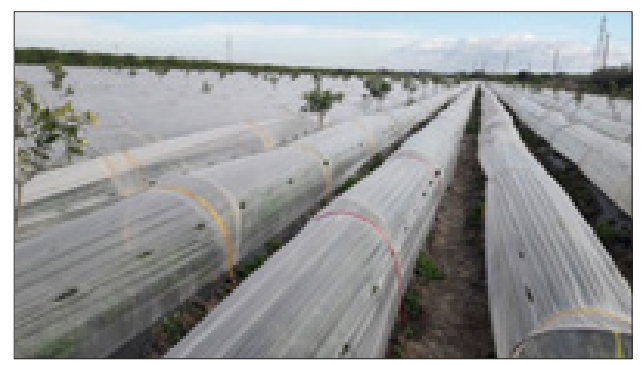

Figure 3: Cover the plastic.

Leaf nematode It is not a problem to use drip pipes in greenhouses and to be covered. However, due to autumn rains, their populations are increasing in open areas in November and February. Dish plants should be destroyed. Propagated rootstock seedlings from which strawberry seedlings are produced should be free of nematodes. Nematode analysis should be done before planting the seedlings to be used. Excess moisture and splashing of water into the leaf stalks should be prevented. In order to prevent the transition of the dishes from the leaves to the healthy leaves, the contact between the plants should be cut. Leaf wetness of plants should be prevented. When entering the rainy period in the open area, it should be covered with plastic earlier. Farmers are not aware of the harm of strawberry leaf nematodes. Strawberry seedlings are kept in water with nematicide before planting, and the strawberry leaf nematode population is reduced (Figure 4). As a result, an integrated struggle should be made to increase efficiency and quality. Fumigant application should be done by solarization before planting against soil pathogens. As the development of healthy plants with good roots will increase yield and quality. Sprinkler irrigation should not be done in seedling production areas to decrease the population of leaf nematode. Producers should take measures to prevent leaf wetness of plants to reduce the damage of strawberry leaf nematode.

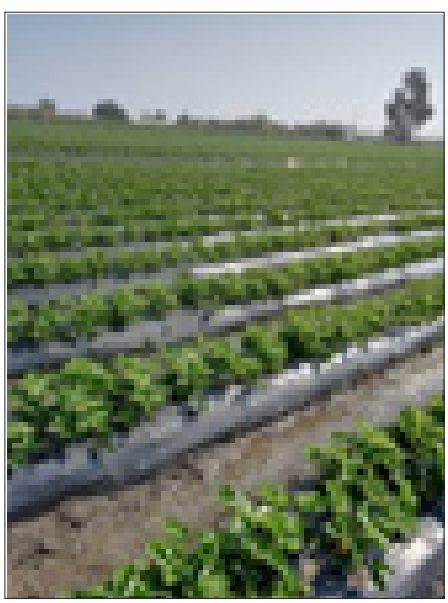

Figure 4: Open field.

\section{References}

1. TUiK (2018) Turkish Statistical Institute, Turkey.

2. Benlioglu S, Yildiz A, Boz O, Benlioglu K (2014) Soil disinfestation options in Aydın province, Turkey, strawberry cultivation. Phytoparasitica 42: 397-403.

3. Gamliel A, Siti M, Arbel A, Katan J (2009) Soil solarization as a component of the integrated management of Fusarium crown and root rot in tomato. Acta Horticulturae 808: 321- 326.

4. Yücel S, Günaçtı H (2019) Effects of soil solarization and fumigant applications on fungal root diseases in tomato and strawberry greenhouses in Turkey. Toprak Su Dergisi 8(2): 107-113.

5. Özarslandan A (2019) Identification of strawberry leaf nematode (Aphelenchoides fragariae) (Nemata: Aphelenchida) from a strawberry greenhouses of Eastern Mediterranean Region. KSU J Agric Nat 22(1): 52-56.

6. Özarslandan A (2019) Detection of strawberry leaf nematode (Aphelenchoides fragariae) (Nemata: Aphelenchida) strawberry production areas in Silifke of Mersin. $3^{\text {rd }}$ International Mediterranean Symposium, Mersin, Turkey, pp. 10-31. 